\title{
Hepatitis B virus DNA in saliva, urine, and seminal fluid of carriers of hepatitis $B$ e antigen
}

\author{
P KARAYIANNIS, D M NOVICK, A S F LOK, M J F FOWLER, J MONJARDINO, \\ H C THOMAS
}

\begin{abstract}
Concentrated samples of saliva, urine, and seminal fluid from 23 men with chronic liver disease who were positive for hepatitis $B$ e antigen were examined for the presence of hepatitis $B$ virus deoxyribonucleic acid (HBV-DNA) by molecular hybridisation. HBV-DNA was detected in saliva from 15 of 17 men (88\%), urine from 12 of 22 men ( $55 \%)$, and seminal fluid from 13 of 21 men (62\%). The presence of hepatitis $B$ virus in such secretions has important epidemiological implications for heterosexual and homosexual contact.
\end{abstract}

\section{Introduction}

The parenteral mode of transmission of hepatitis $B$ virus is wel ${ }^{l}$ established, but non-parenteral (or inapparent parenteral) routes of exposure may also play a part in infectivity; this may explain the high incidence of transmission of hepatitis $B$ virus among homosexual men and family contacts of carriers of hepatitis B virus. ${ }^{1-7}$ Several groups have therefore examined bodily fluids and secretions for the presence of hepatitis B surface antigen ( $\mathrm{HBsAg}$ ), which has been found in saliva, ${ }^{8-10}$ urine, ${ }^{9-12}$ semen, ${ }^{8}$ breast milk, ${ }^{13} 14$ vaginal secretions and menstrual blood, ${ }^{15} 16$ and pancreatic and biliary secretions. ${ }^{17}$ There are conflicting reports of its presence in faeces. ${ }^{1018-20}$ The detection of HBsAg alone, however, does not by itself denote potential infectivity as $\mathrm{HBsAg}$ may be found in the absence of infectious virions. The potential for transmission of

\footnotetext{
Academic Departments of Medicine and Physiology, Royal Free Hospital School of Medicine, London NW3 2PF

P KARAYIANNIS, BSC, PHD, research assistant

D M NOVICK, $M D$, research fellow

A S F LOK, MB, MRCP, research fellow

M J F FOWLER, BSC, PHD, research assistant

J MONJARDINO, MB, PHD, reader in physiology

H C THOMAS, PHD, FRCP, professor of medicine

Correspondence to: Professor H C Thomas.
}

hepatitis B virus by inapparent parenteral means has therefore not been fully evaluated.

The presence of hepatitis $\mathrm{B}$ virus particles can be detected by molecular hybridisation techniques, which detect hepatitis $\boldsymbol{I}$ virus deoxyribonucleic acid (HBV-DNA). ${ }^{21-25}$ The presence of HBV-DNA indicates potential infectivity. In this study we examined concentrated saliva, urine, and seminal fluid for the presence of HBV-DNA by molecular hybridisation. The results were correlated with serum concentrations of HBV-DNA and with the possible contamination of saliva and urine with blood.

\section{Patients and methods}

Twenty three patients with chronic hepatitis $B$ virus infection (positive for $\mathrm{HBsAg}$, hepatitis $\mathrm{B}$ e antigen ( $\mathrm{HBeAg}$ ), and HBV-DNA) who attended this hospital for antiviral treatment participated in the study. Two carriers positive for $\mathrm{HBsAg}$ and anti-HBe and a healthy subject negative for HBsAg served as controls. Eighteen of the participants provided samples of all the secretions that were requested (group 1). The remaining eight patients (group 2) either failed to provide some of the samples or provided insufficient samples.

Patients were issued with receptacles for the specimens and were asked to collect about $3 \mathrm{ml}$ saliva when they woke up in the morning and before brushing their teeth; $50 \mathrm{ml}$ urine voided in the morning; and a sample of semen obtained preferably after abstention from sexual activity for three days. A specimen of serum was obtained on the same day by venepuncture.

All specimens were processed within two to three hours after collection. Specimens of saliva and urine were tested for the presence of blood by Hemastix (Ames Division, Miles Laboratories, Slough) before concentration. Samples of semen were allowed to liquefy at room temperature, and the sperm were then separated from the seminal fluid by centrifugation.

The saliva, urine, and seminal fluid were next placed in dialysis tubing and concentrated against macrogol 6000 (polyethylene glycol 6000) (BDH Chemicals, Poole). Saliva and seminal fluid were concentrated to $250 \mu \mathrm{l}$ irrespective of starting volume. Urine was concentrated from a $25 \mathrm{ml}$ starting volume to $250 \mu \mathrm{l}$ (100-fold concentration). All samples were then stored at $-20^{\circ} \mathrm{C}$.

The methods of HBV-DNA extraction, preparation of radiolabelled probes by nick translation, and molecular hybridisation have been described previously. ${ }^{23}$ 26-28 Viral DNA from saliva, urine, and seminal fluid was extracted as for serum. Autoradiographs 
were obtained by exposure of hybridised DNA on nitrocellulose filters for 24-48 hours. Samples from four patients were also analysed by agarose gel electrophoresis and Southern blotting followed by hybridisation with HBV-DNA labelled with phosphorus-32.26

\section{Results}

The table shows the incidence of HBV-DNA in saliva, urine, and seminal fluid. HBV-DNA was detected in $55-88 \%$ of the samples from the $\mathrm{HBeAg}$ positive patients and none from the controls. Moreover, in group 1 at least one sample from every patient was positive for HBV-DNA and all 15 patients were therefore potentially infectious. Nine of these patients provided samples on a second occasion and similar positivity rates were obtained.

To confirm that the results obtained were due to HBV-DNA, samples were examined by Southern blotting to investigate the molecular species of the hybridisable DNA. Hybridisation signals in the form of smears covering the size range $2 \cdot 0-2 \cdot 8 \mathrm{~kb}$ were seen. These corresponded to the heterogeneous population of HBV-DNA associated with virions. The intensity of the autoradiography spots (figure) from all secretions was generally weak and required at least 48 hours of film exposure before becoming visible. This was particularly true for the samples of seminal fluid. Several specimens of saliva and urine, however, produced strong spots within 24 hours. Serum concentrations of HBV-DNA ranged from $8.94 \times 10^{-11}$ to $2.77 \times 10^{-9} \mathrm{mmol} / \mathrm{l}(186$ to $5760 \mathrm{pg} / \mathrm{ml})$.

Samples of urine and saliva were examined for blood. None of the samples of urine contained detectable amounts of blood. In the saliva, however, blood was detected in varying amounts (two trace, four small, two moderate, and three large) in 11 of the 17 samples positive for HBV-DNA.

Prevalence of $H B V-D N A$ in saliva, urine, and seminal fluid. Figures are proportions of patients (and \%)

\begin{tabular}{ccccc}
\hline & Saliva & Urine & Seminal fluid & Serum \\
\hline Group 1 & $13 / 15(86 \cdot 6)$ & $9 / 15(60)$ & $8 / 15(53 \cdot 3)$ & $15 / 15(100)$ \\
Group 2 & $2 / 2(100)$ & $3 / 7(42 \cdot 8)$ & $5 / 6(83)$ & $8 / 8(100)$ \\
\hline Total & $15 / 17(88 / 2)$ & $12 / 22(54 \cdot 5)$ & $13 / 21(61 \cdot 9)$ & $23 / 23(100)$ \\
\hline Controls & $0 / 3$ & $0 / 3$ & $0 / 3$ & $0 / 3$
\end{tabular}

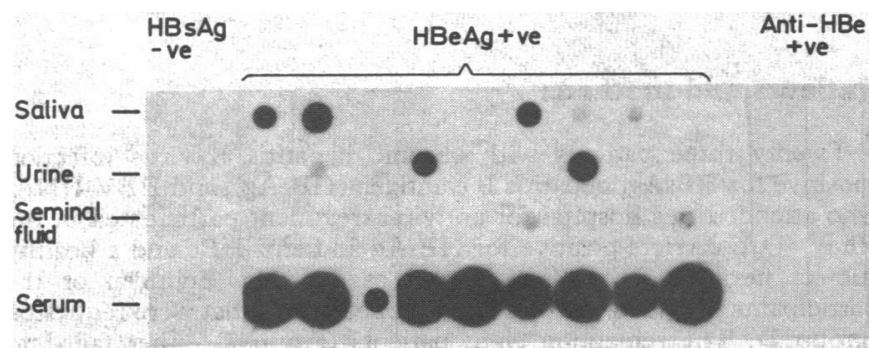

Composite autoradiograph of nitrocellulose filters bearing samples of saliva, urine, seminal fluid, and serum probed for HBV-DNA using HBV-DNA labelled with phosphorus-32. Black areas indicate presence of HBV-DNA in samples. Intensity of spot indicates amount of HBV-DNA present.

\section{Discussion}

The detection of HBV-DNA in saliva, urine, and seminal fluid by molecular hybridisation indicates the likely presence of hepatitis $B$ virus particles in these secretions and establishes them as potential vehicles of infectivity. Although it has been suspected that non-parenteral transmission of hepatitis B virus may be due to contamination of such secretions with virions, this can now be substantiated by the sensitive technique of molecular hybridisation.

Of the concentrated saliva specimens, $87 \%$ were positive for HBV-DNA, and in some large amounts were present. The detection of HBV-DNA in some of these may have been due to the presence of oral or gingival lesions as blood was detected in $64 \%$ of the samples and this was gross in $31 \%$. In some cases, however, HBV-DNA was detected in saliva with no detectable contamination with blood. Of the concentrated urine specimens, $60 \%$ were positive for HBV-DNA and none were contaminated with blood. This prevalence was higher than previous reports of $\mathrm{HBs} A g$ in urine, ${ }^{910}$ possibly because of the greater degree of concentration achieved here and the more sensitive technique of molecular hybridisation. Seminal fluid was also found to be positive for HBV-DNA. The degree of concentration varied from twofold to 10-fold depending on the volume of the ejaculate.

The presence of HBV-DNA in the above secretions was independent of the amount of HBV-DNA in serum. Although no quantitative measurements were undertaken owing to the difficulty in standardising concentration factors, the amounts detected in the various secretions were small compared with those found in serum. Probably there is transudation or exudation of fluid containing virus from the general circulation into various body fluids rather than active virus replication at the site of secretion.

The presence of HBV-DNA in the various secretions was further confirmed by Southern blotting. Positive autoradiographs were obtained from smears of HBV-DNA sequences in the $2 \cdot 0-2 \cdot 8 \mathrm{~kb}$ region of the gels, where HBV-DNA associated with virions is normally found. ${ }^{26}$

Most of the men investigated were homosexual, and all of them had at least one sample that was positive for HBV-DNA. It has been postulated that the high rate of transmission of hepatitis $B$ virus in homosexual populations is due to contamination of partners with blood from lacerations in the rectum of the passive partner or cuts on the penis of the active partner. ${ }^{20}$ Our results prove that this may not be the only mechanism. Contaminated semen or saliva deposited in the rectum during orogenital and oroanal contact might be alternative modes of transmission among homosexual men. Similarly, consorts of heterosexual men are at risk of infection from their partner's secretions. Indeed the potential of saliva and semen to transmit hepatitis B virus infection has been shown experimentally in primates. ${ }^{29} 30$

\section{References}

1 Dienstag JL. Toward the control of hepatitis B. N Engl f Med 1980;303:874-6. spread of hepatitis B infection. Ann Intern Med 1975;83:489-95.

3 Szmuness W, Stevens CE, Harley EJ, et al. Hepatitis B vaccine demonstration of efficacy in a controlled clinical trial in a high-risk population in the United States. N Engl $f$ Med 1980;303:833-41.

4 Redeker AG, Mosley JW, Gocke DJ, McKee AP, Pollack W. Hepatitis B immune globulin as a prophylactic measure for spouses exposed to acute type B hepatitis. N Engl f Med 1975;273:1055-9.

5 Koff RS, Slavin MM, Connelly LJD, Rosen DR. Contagiousness of acute hepatitis B secondary attack rates in household contacts. Gastroenterology $1977 ; 72: 297-300$

6 Inaba N, Ohkawa R, Matsuura A, Kudoh J, Takqumizawa H. Sexual transmission of hepatitis $B$ surface antigen. Infection of husbands by $\mathrm{HBsA}_{8}$ Perill RP, Belb 1 . Br Vener Dis 1979;55:366-8.

Dis activity, and infection of hous

8 Heathcote J, Cameron CH, Dane DS. Hepatitis B antigen in saliva and semen Lancet $1974 ; \mathrm{i}: 71-5$.

9 Sung JL, Chen DS. Hepatitis B surface antigen in saliva, urine and ascites

[Abstract]. Hepatogastroenterol 1983;30:183.
10 Villarejos VM, Visona KA, Gutierrez A, Rodriguez A. Role of saliva, urine and feces in the transmission of type B hepatitis. N Engl $\mathcal{F}$ Med 1974;291:1375-8. 1 Blainey JD, Earle A, Flewett TH, Williams LKL. Is the urine infective in serum hepatitis? Lancet $1971 ; 1: 797$. 1971;231:266-7.

13 Linnemann CC, Goldberg S. HBsAg in breast milk. Lancet 1974;ii:155.

14 Boxall EH, Flewett TH, Dane DS, Cameron CH, MacCallum FO, Lee TW. Hepatitis B surface antigen in breast milk. Lancet 1974 ;ii:1007-8.

15 Darani M, Gerber M. Hepatitis-B antigen in vaginal secretions. Lancet 1974, ii: 1008 .

16 Mazzur $\dot{S}$. Menstrual blood as a vehicle of Australia antigen transmission.

Lancet 1973;i :749.
17 Hoefs JC, Renner IG, Ashcavai M, Redeker AC. Hepatitis B surface antigen in pancreatic and biliary secretions. Gastroenterology 1980;79:191-4. einman SV, Berris B, Rebane A, Sinclair JC, Wilson S, Wrobel D. Failure to B surface antigen in faeces of HBsAg-positive persons. $f$ Infect Dis 1979;140:407-10

19 Moodie JW, Stannard LM, Kipps A. The problem of the demonstration of hepatitis B antigen in faeces and bile. F Clin Pathol 1974;27:693-7.

20 Reiner NE, Judson FN, Bond WW, Francis DP, Petersen NJ. Asymptomatic rectal mucosal lesions and hepatitis $B$ surface antigen at sites of sexual contac in homosexual men with persistent hepatitis B virus infection. Ann Intern Med

21 Brechot C, Scotto J, Charnay P, et al. Detection of hepatitis B virus DNA in liver and serum. A direct appraisal of the carrier state. Lancet 1981 ;ii:765-7. 
DNA in the sera of $\mathrm{HBsAg}$ carriers: a marker of active hepatitis B virus replication in the liver. Hepatology $1981 ; 1: 386-91$.

The detection of $\mathrm{HBV}$ DNA in sow DNA in serum by molecular hybridisation: a more sensitive method

24 dettoction of complete $\mathrm{HBV}$ particles. F Med Virol 1982;9:273-80.

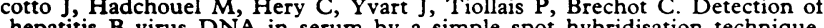
hepatitis B virus DNA in serum by a simple spot hybridisation technique. Comparison with results for other viral markers. Hepatology 1983;3:279-84. Lieberman HM, La Brecque DR, Kew MC, Hadziyannis SJ, Shafritz DA.

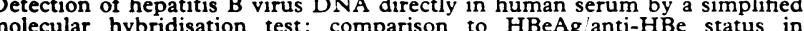
molecular hybridisation test: comparison

26 Monjardino J, Fowler MJF, Montano L, et al. Analysis of hepatitis virus DNA in the liver and serum of $\mathrm{HBe}$ antigen positive chimpanzee carriers. $\mathcal{F}$ Med Virol 1982;9:189-99.
27 Karayiannis P, Fowler MJF, Lok ASF, Greenfield C, Monjardino J, Thomas HC. Detection of serum HBV-DNA by molecular hybridisation: correlation with $\mathrm{HBeAg}$ /anti-HBe status, racial origin, liver histology and hepatocellular

28 Weinstock R, Sweet R, Weiss M, Cedar R, Axel R. Intragenic DNA spacers interrupt the oralbumin gene. Proc Natl Acad Sci USA 1978;75:1295-303.

29 Bancroft WH, Snitbhan R, Scott RM, et al. Transmission of hepatitis $B$ virus to gibbons by exposure to human saliva containing hepatitis $\mathrm{B}$ surface antigen. I Infect Dis 1977;135:79-85.

30 Alter HJ, Purcell RH, Gerin JL, et al. Transmission of hepatitis B to chimpanzees by hepatitis $B$ surface antigen-positive saliva and semen. Infect Immun 1977;16:928-33.

\title{
Chronic ulceration of the leg: extent of the problem and provision of care
}

\author{
M J CALLAM, C V RUCKLEY, D R HARPER, J J DALE
}

\begin{abstract}
A postal survey in two health board areas in Scotland, encompassing a population of about one million, identified 1477 patients with chronic ulcers of the leg. Women outnumbered men by a ratio of $2 \cdot 8: 1$. The median age of the women was 74 and of the men 67 . Seventy two (5\%) were hospital inpatients, $174(12 \%)$ were managed jointly by the primary care team and outpatient departments, and $1201(83 \%)$ were managed entirely in the community.

Efforts to improve the management of chronic ulcers of the leg should focus on primary health care.
\end{abstract}

\section{Introduction}

Chronic ulceration of the leg appears to have perplexed physicians since medical records began. Although there are many reports on its management, little information is available on the overall size and extent of the problem or its clinical course.

Two European surveys into venous disease have been made, providing data on the prevalence of leg ulceration. The first was a study, based on a questionnaire, of the adult population of Klatov in Bohemia in 1961 by Bobek et al. ${ }^{1}$ Those people who indicated that they had evidence of venous disease were subsequently examined. This survey showed that the prevalence of leg ulceration, either open or healed, was $1 \%$. The second and more recent study, of factory workers in Basle, Switzerland, showed a similar proportion. ${ }^{2}$

Information concerning the United Kingdom is almost nonexistent. In 1929 Dickson-Wright suggested a prevalence of $0.5 \%$ but admitted that this figure was an estimate. ${ }^{3}$ In 1951 Boyd et al arrived at a similar figure based on the returns of patients registered as off work due to leg ulceration, ${ }^{4}$ but this figure was probably an underestimate. In a study supplementary to that

\section{Leith Hospital, Edinburgh}

M J CALLAM, MB, FRCSED, senior surgical registrar

Vascular Surgical Unit, Royal Infirmary, Edinburgh

C V RUCKLEY, MB, FRCSED, consultant surgeon

Surgical Unit, Royal Infirmary, Falkirk

D R HARPER, MD, FRCSED, consultant surgeon

Department of Nursing, Lothian Health Board, Edinburgh J J DALE, SRN, MSC, senior nursing officer

Correspondence to: Mrs J J Dale, Lothian and Forth Valley Leg Ulcer Study, 40 Colinton Road, Edinburgh. reported here and based on patients in a group practice in Edinburgh we recently estimated that $1 \%$ of adults suffer from chronic leg ulcers. ${ }^{5}$

Much of the information in reports on leg ulcers is based on small, selected populations, usually patients attending outpatient departments. An understandable conclusion that might be drawn from such reports is that all leg ulcers are managed by dermatologists, surgeons, or physiotherapists. A preliminary survey by our own group, however, showed that most patients were cared for in the community by district nurses and represented a formidable problem for the primary care services not only in terms of numbers but also in various aspects of management. We concluded that the first step towards improving care was to obtain better information on the scale of the problem, the clinical course of the condition, and how care was being provided.

The Lothian and Forth Valley leg ulcer study was therefore set up in 1981. This paper reports the first phase, the main aims of which were to establish a point prevalence of leg ulcers and to find out who was providing the care.

\section{Methods}

The survey was carried out in 1981-2 in the neighbouring health board areas of Lothian and Forth Valley, which have a mixed urban and rural population of about one million. The objective was to identify all patients receiving treatment for chronic leg ulceration from any branch of the National Health Service at the time of the survey.

To identify all patients receiving treatment in the community recording forms were sent to all general practitioners, district and occupational nurses, and wardens of old people's homes. To identify patients receiving either outpatient or inpatient care at a hospital forms were sent to outpatient departments, physiotherapy departments, and inpatient wards of general hospitals and all acute and long stay hospitals. In each case the correspondent was asked to identify all the patients currently undergoing treatment for active chronic leg ulceration or who had received treatment within three months. Efforts were made to obtain replies from non-responders by means of follow up letters and telephone calls.

The resulting returns were cross checked to ensure that patients reported from more than one source were included only once in the final total.

\section{Results}

Of the 572 general practitioners approached, only 37 refused to cooperate with the study. Complete returns were obtained from all other correspondent groups. Notifications of 2128 patients were received, of which 651 were reported from more than one source, giving a total of 1477 patients $(1765(83 \%)$ were reported by general practitioners, district nurses, occupational health services, and old people's homes; and $104(5 \%)$ by physiotherapy departments, $148(7 \%)$ by 